\title{
ANALISIS PENGARUH CUSTOMER DELIGHT (Adil dan Jujur(Justice), Pelayanan Terbaik (Esteem) dan Surprised/Finishing Touch) TERHADAP LOYALITAS PELANGGAN ES TELER 77 DI JAKARTA PUSAT TAHUN 2019
}

Oleh:

\author{
Rina Ayu Vildayanti \\ Fakultas Ekonomidan Bisnis, Universitas Budi Luhur, Jakarta \\ Email: \\ rina_ayu_vildayanti@yahoo.com
}

\begin{abstract}
Indonesia has long applied the franchise system business, which is the owner of Es Teler 77, Sukyatno Nugroho began in 1987. After nearly 3 decades, Es Teler 77 has continued to develop in serving food and beverages with authentic and quality Indonesian recipes. The purposes of this research are to analyze the effect of customer delight (justice, esteem and surprised/finishing touch) to customer loyalty at Es Teler 77 on Central Jakarta in 2019. The research methodology used is quantitative method with cross-section data and primary, which will be gain from the questionnaire. Technical sampling using purposive sampling on the year 2019 data. Analysis data technique which will be used is multiple linear regression by doing validity tests, reliability tests, model stability tests, linearity tests, normality tests, classical assumption tests (multicolinearity tests, heteroskedasticity tests), $t$-statistic hypothesis and f-statistic to test 5\% significance of the effects. Results of the research show that partially, justice, esteem, and finishing touch are positively and significantly effecting to customer loyalty at Es Teler 7, meanwhile simultaneously, the independent variable; justice, esteem and finishing touch relate significantly to the dependent variable; customer loyalty at Es Teler 77. Determination coefficiencies of this research indicate that $72.64 \%$ of independent variable; justice, esteem and finishing touch to explain the fluctuations of dependent variable customer loyalty at Es Teler 77, whereas the rest $27.36 \%$ affected by the other independent variables.
\end{abstract}

Keywords: Customer Loyalty, Esteem, Finishing Touch, Justice. 


\begin{abstract}
ABSTRAK
Indonesia sudah lama menerapkan bisnis sistem waralaba yaitu pemilik usaha Es Teler 77, Sukyatno Nugroho dimulai pada tahun 1987. Setelah hampir 3 dasawarsa, Es Teler 77 terus berkembang dalam menyajikan makanan dan minuman dengan resep asli Indonesia yang bermutu dan berkualitas. Penelitian ini bertujuan menganalisis pengaruh kesenangan pelanggan (adil dan jujur, pelayanan terbaikdan surprised terhadap loyalitas pelanggan Es Teler 77 di Jakarta Pusat tahun 2019. Metodologi penelitian yang digunakan adalah metode kuantitatif dengan data cross section dan data primer yang diperoleh dari penyebaran kuesioner. Teknik pengambilan sampel menggunakan metode purposive sampling dengan data pada tahun 2019. Teknik analisis data yang digunakan adalah regresi linier berganda dengan melakukan uji validitas, uji reliabilitas, uji stabilitas model, uji linieritas, uji normalitas, uji asumsi klasik (uji multikolinearitas, uji heteroskedastisitas) dan uji hipotesis t-statistik serta f-statistik untuk menguji pengaruh secara bersama-sama dengan tingkat signifikansi 5\%. Hasil dari penelitian ini menunjukkan bahwa secara parsial variabel adil dan jujur (justice), pelayanan terbaik (esteem), dan surprised/finishing touch berpengaruh positif dan signifikan terhadap loyalitas pelanggan Es Teler 77. Sementara itu secara simultan variabel bebas adil dan jujur (justice), pelayanan terbaik (esteem), dan surprised/finishing touch secara bersama-sama memiliki hubungan yang signifikan terhadap variabel terikatnya yaitu loyalitas pelanggan Es Teler 77. Koefisiensi determinasi dari penelitian ini menunjukkan angka sebesar $72.64 \%$ memperlihatkan bahwa variasi variabel bebas adil dan jujur (justice), pelayanan terbaik (esteem), dan surprised/finishing touch mampu menjelaskan variasi naik turunnya variabel terikat loyalitaspelanggan Es Teler 77 sebesar $72.64 \%$ sedangkan sisanya sebesar $27.36 \%$ dipengaruhi oleh variabel bebas lainnya.
\end{abstract}

Kata Kunci: Adil dan Jujur, Loyalitas Konsumen, Pelayanan Terbaik, Surprised.

\title{
A. PENDAHULUAN
}

Kegiatan ekonomi mikro merupakan kegiatan usaha yang dapat memperluas lapangan pekerjaan serta memberikan pelayanan ekonomi secara luas kepada masyarakat, agar dapat berperan dalam proses pemerataan dan peningkatan masyarakat, mendorong pertumbuhan ekonomi serta berperan mewujudkan stabilitas nasional. Selain itu, usaha mikro adalah satu pilar utama ekonomi nasional yang mendapatkan kesempatan utama, dukungan, perlindungan serta pengembangan yang secara luas sebagai wujud pihak yang tegas kepada kelompok usaha ekonomi rakyat, tanpa harus mengabaikan peranan penting usaha besar dan badan usaha milik pemerintah.

Franchise pertama kali dimulai di Amerika oleh Singer Sewing Machine Company, produsen mesin jahit Singer pada 1851. Pola itu kemudian diikuti oleh perusahaan otomotif General Motor Industri yang melakukan penjualan kendaraan 
bermotor dengan menunjuk distributor franchise pada tahun 1898. Di Indonesia kata Franchise di artikan sebagai waralaba yaitu lebih untung, dengan pertumbuhan franchise berawal dari masuknya waralaba asing pada tahun 8090an yaitu KFC, Mc Donald, Burger King adalah sebagian dari jejaring waralaba asing yang masuk di Indonesia. Para pelaku bisnis juga sudah banyak yang menggunakan sistem waralaba ini karena hasil yang didapat bisa dibagi dengan kesepakatan dengan si pemilik waralaba. Para investor biasanya lebih suka cenderung memberikan modalnya kepada badan usaha yang sudah mempunyai kekuatan dari segi finansial dan segi pemasaran. Dengan menggunakan bisnis waralaba, sistem manajemen finansial telah di tetapkan oleh pemilik waralaba utama , sehingga tidak perlu lagi pusing dalam mengatur sistem finansial seperti membangun bisnis baru. Pemilik waralaba sebelumnya telah memberikan pelatihan manajemen finasial, pemasok bahan baku, pemasaran dan periklanan agar terkendali dengan baik.

Di Indonesia sendiri yang sudah lama menerapkan bisnis waralaba adalah pemilik usaha Es Teler 77. Pada tahun 1987, Sukyatno Nugroho yang pertama kali menerapakan sistem waralaba. Sejak tahun itu hanya menjual minuman dingin berupa buah-buahan segar seperti nangka, alpukat dan kelapa, dengan racikan sirup yang sangat istimewa untuk di nikmati konsumen. Setelah hampir 3 dasawarsa, Es Teler 77 terus berkembang dalam menyajikan makanan dan minuman dengan resep asli Indonesia yang bermutu dan berkualitas.Tidak sedikit di negara lain menyukai makanan-makanan asli dari Indonesia, karena kaya akan rempah-rempah yang ada di setiap daerah tertentu. Masyarakat di luar negeri sangat antusias dengan rasa khas makanan Indonesia dengan racikan rempahrempah oleh pembuat makanan asal Indonesia. Banyak chef Indonesia yang bekerja di restaurant ternama memperkenalkan makanan-makanan kepada orangorang asing di negara lain agar mereka tahu Indonesia banyak beraneka ragam makanan-makanan yang sangat lezat bukan hanya di Negara Indonesia sendiri tetapi di luar negeri. Untuk itu banyak turis asing yang berkunjung ke Indonesia, bukan hanya untuk sekedar berlibur ke tempat wisata bagus melainkan untuk mencicipi makanan dari berbagai daerah yang ada di kota-kota yang ada.

Kesenangan pelanggan (customer delight) adalah reaksi pelanggan ketika mereka menerima suatu pelayanan atau produk yang memberikan nilai melebihi harapan mereka. Untuk menciptakan kesenangan (delight), perusahaan harus mengerti keinginan pelanggan, mengantisipasi kebutuhan pelanggan, memberikan lebih apa yang diharapkan pelanggan, dan membuat setiap momen dari aspek dalam hubungan ini menjadi sesuatu yang menyenangkan, atau menjadi pengalaman yang menyenangkan. Pelanggan yang marah atau tidak puas akan menimbulkan masalah karena mereka dapat berpindah ke perusahaan lain dan menyebarkan berita negatif dari mulut ke mulut (Christopher H Lovelock, 2007). Suatu perusahaan mungkin beralasan, produk dan jasa jarang ada yang sempurna dan orang sulit disenangkan. Perusahaan-perusahaan yang mengambil pendekatan ini mungkin akan menghadapi masalah karena banyak bukti menunjukkan bahwa memuaskan pelanggan saja tidaklah cukup. Pelanggan yang sedikit puas atau netral dapat direbut oleh pesaing. Namun, pelanggan yang senang akan tetap loyal walaupun ada tawaran yang menarik dari pesaing. Kepuasan pelanggan 
memainkan peran yang sangat penting dalam industri yang sangat bersaing karena terdapat perbedaan yang sangat besar dalam loyalitas antara pelanggan yang sekedar puas dan yang benar-benar puas atau senang.

Pada tahun 1981, seorang Ibu bernama Murniati Widjaja memenangkan lomba membuat Es Teler di Jakarta. Bermula dari lomba inilah, timbul sebuah gagasan untuk membuka warung tenda sederhana di plataran teras sebuah pertokoan duta merlin di kawasan Jakarta Pusat. Warung sederhana dengan nama Es Teler 77 ini merupakan usaha keluarga yang ditangani langsung oleh Ibu Murniati sendiri bersama suaminya Trisno Budijanto, anak dan mantunya, Yenny Setia Widjaja dan Sukyatno Nugroho. Pada tahun 1987, Sukyatno Nugroho mewaralabakan Es Teler 77 yang dengan ini merupakan usaha makanan cepat saji asli Indonesia pertama yang menerapkan sistem waralaba, mengikuti perkembangan tren gaya hidup. Pada tahun 1994, seluruh gerai Es Teler 77 dipindahkan dari kios ke mal dan plaza. Kehadiran Es Teler 77 di arena pusat perbelanjaan modern ini memperluas wawasan kuliner Indonesia, dimana Es Teler 77 memperkenalkan konsep makanan cepat saji (fastfood) yang menyajikan makanan dan minuman jajanan populer Indonesia. Setelah lebih dari tiga dasawarsa, Es Teler 77 terus berkembang dengan menyajikan produk makanan dan minuman dengan resep orisinil yang bermutu dan berkualitas kepada pelanggan di pelosok Indonesia dan juga mancanegara. Dengan 180 gerai lebih yang tersebar di berbagai daerah di Indonesia, Es Teler 77 bukan hanya meningkatkan citra makanan Indonesia di negeri sendiri tetapi juga memperkenalkan makanan Indonesia ke mancanegara, hingga saat ini Es Teler 77 dapat dikunjungi di Singapura, Malaysia dan Melbourne, Australia. Dengan banyaknya gerai yang ada, diharapkan dapat membangun loyalitas dan menciptakan hubungan yang kuat serta erat dengan pelanggan adalah mimpi semua pemasar dan hal ini sering menjadi kunci keberhasilan pemasar jangka panjang. Perusahaan yang ingin membentuk ikatan pelanggan yang kuat harus memperhatikan sejumlah pertimbangan yang beragam.

Loyalitas pelanggan merupakan istilah kuno yang secara tradisional telah digunakan untuk melukiskan kesetiaan dan pengabdian antusias kepala negara, cita-cita, atau individu. Lebih belakangan ini, dalam konteks bisnis, istilah ini telah digunakan untuk melukiskan kesediaan pelanggan untuk terus berlangganan pada sebuah perusahaan dalam jangka panjang, dengan membeli dan menggunakan barang dan jasanya secara berulang-ulang dan lebih baik lagi secara ekslusif, dan dengan suka rela merekomendasikan produk perusahaan tersebut kepada teman-teman dan rekan-rekannya.

Berdasarkan uraian diatas, maka penulis tertarik untuk mengkaji hal tersebut diatas dan mengangkat penelitian yang berjudul :"Analisis Pengaruh Customer Delight (Adil dan Jujur (Justice), Pelayanan Terbaik (Esteem) dan Surprised/ Finishing Touch) Terhadap Loyalitas Pelanggan Es Teler 77 di Jakarta Pusat Tahun 2019”. 


\section{B. KAJIAN PUSTAKA}

\section{Kesenangan Pelanggan (Customer Delight)}

"Customer delight is conceptualized as an emotional response, which result from surprising and positive levels of performance". Kesenangan pelanggan di konseptualisasikan sebagai respons emotional,hasil dari kejutan dan tingkat kinerja yang positif. Kesenangan pelanggan (customer delight) adalah reaksi pelanggan ketika mereka menerima suatu pelayanan atau produk yang memberikan nilai melebihi harapan mereka. Untuk menciptakan kesenangan (delight), perusahaan harus mengerti keinginan pelanggan, mengantisipasi kebutuhan pelanggan, memberikan lebih apa yang diharapkan pelanggan, dan membuat setiap momen dari aspek dalam hubungan ini menjadi sesuatu yang menyenangkan, atau menjadi pengalaman yang menyenangkan.

Pelanggan yang marah atau tidak puas akan menimbulkan masalah karena mereka dapat berpindah ke perusahaan lain dan menyebarkan berita negatif dari mulut ke mulut (Christopher H Lovelock, 2007). Suatu perusahaan mungkin beralasan, produk dan jasa jarang ada yang sempurna dan orang sulit disenangkan. Perusahaan-perusahaan yang mengambil pendekatan ini mungkin akan menghadapi masalah karena banyak bukti menunjukkan bahwa memuaskan pelanggan saja tidaklah cukup. Pelanggan yang sedikit puas atau netral dapat direbut oleh pesaing. Namun, pelanggan yang senang akan tetap loyal walaupun ada tawaran yang menarik dari pesaing. Kepuasan pelanggan memainkan peran yang sangat penting dalam industri yang sangat bersaing karena terdapat perbedaan yang sangat besar dalam loyalitas antara pelanggan yang sekedar puas dan yang benar-benar puas atau senang.

\section{a. Adil \& Jujur (Justice)}

Menurut Philip Kotler (2010) suatu perusahaan tidak boleh menjual produk yang berkualitas rendah dengan harga yang tinggi. Pemasaran (marketing) yang benar adalah pemasaran (marketing) yang adil, dimana harga dan kualitas produk harus selaras. Begitu perusahaan mencoba untuk menipu dengan memberikan produk dengan kualitas rendah, tetapi mengatakan produk tersebut memiliki kualitas yang bagus, konsumen akan meninggalkan kita, maka tetapkan harga yang wajar sesuai dengan kualitas produk. Pemasar bertugas untuk selalu meningkatkan QCD (quality, cost dan delivery) dalam sebuah proses bisnis. Selain itu juga selalu menepati janji yang diberikan kepada pelanggan, pemasok dan distributor. Jangan pernah mencoba untuk menipu atau berlaku tidak jujur dalam hal kualitas, kuantitas, harga dan waktu penyampaian, serta setiap saat perusahaan harus meningkatkan berbagai aspek dari proses bisnis perusahaan tersebutJustice merupakan suatu kondisi dimana pelanggan merasa mendapatkan perlakuan yang adil dan jujur ketika melakukan transaksi dengan perusahaan, Edwards (2002) menyatakan bahwa perlakuan adil berpotensi menimbulkan delight. 


\section{b. Pelayanan Terbaik (Esteem)}

Perusahaan harus mempertahankan hubungan yang baik dengan pelanggan, terkadang dapat juga mengenal pelanggan secara personal dan satu persatu, sehingga perusahaan dapat memiliki gambaran utuh mengenai kebutuhan, keinginan, preferensi dan perilaku pelanggan, sehingga akhirnya akan memberikan pelayanan terbaik. Ini adalah salah satu prinsip dari CRM (customer relationship management) dan cara untuk menarik pelanggan emosional dan rasional yang kuat terhadap produk kita. Pelanggan juga dapat menjadi pendukung terkuat suatu produk melalui pemasaran word of mouth, "Pandanglah pelanggan sebagai pelanggan seumur hidup" (Philip Kotler, 2010). Pelayanan terbaik (esteem) adalah suatu kondisi dimana pelanggan merasa mendapatkan pelayanan yang sangat baik dari perusahaan, sehingga menimbulkan perasaan diistimewakan. Edwards (2002) menyatakan bahwa pelanggan yang merasa diperlakukan secara personal, diperhatikan self esteem mereka dan merasa nyaman, maka akan berpotensi menimbulkan delight.

\section{c. Surprised/Finishing Touch}

Menurut Philip Kotler (2010), jangan pernah membuat pelanggan kesulitan untuk menemukan perusahaan. Di era ekonomi global seperti sekarang, akses informasi teknologi dan internet merupakan suatu keharusan, tetapi pemisahan digital, perbedaan sosiokultural antara orang-orang yang memiliki akses ke internet serta teknologi digital dan yang tidak memiliki akses masih merupakan sebuah tantangan di dunia. Perusahaan yang dapat menjembatani pemisahan ini akan dapat memperbesar basis pelanggannya. Bisnis pelayanan tidak hanya terbatas pada hotel atau restoran. Apapun jenis usaha yang di miliki, kita harus memiliki semangat untuk mau melayani pelanggan. Layanan (service) harus menjadi sebuah panggilan hati, bukan hanya sebuah pekerjaan atau tugas semata. Layanilah pelanggan dengan tulus dan penuh empati disertai surprised / finishing touch yang baik, sehingga nantinya pelanggan pasti membawa kenangan positif dari pengalaman yang mereka dapatkan. Surprised / Finishing Touch merupakan kondisi dimana pelanggan merasa mendapatkan pelayanan atau fasilitas yang tidak pernah diduga sebelumnya, teori ini dirujuk dari penelitian Oliver, et.al. (1997) dimana surprised merupakan salah satu fakta penting dalam delight. Edwards (2002) menyatakan bahwa pelanggan perlu untuk mendapatkan rasa percaya dan merasa aman.

\section{Loyalitas Konsumen(Customer Loyalty)}

Loyalitas (loyalty) merupakan istilah kuno yang secara tradisional telah digunakan untuk melukiskan kesetiaan dan pengabdian antusias kepala negara, cita-cita, atau individu. Belakangan ini, dalam konteks bisnis, istilah ini telah digunakan untuk melukiskan kesediaan pelanggan untuk terus berlangganan pada sebuah perusahaan dalam jangka panjang, dengan membeli dan menggunakan barang dan jasanya secara berulang-ulang dan lebih baik lagi secara ekslusif, dan dengan suka rela merekomendasikan produk perusahaan tersebut kepada temanteman dan rekan-rekannya (Christopher H Lovelock, 2007). Membangun loyalitas 
(loyalty) menciptakan hubungan yang kuat dan erat dengan pelanggan adalah mimpi semua pemasar dan hal ini sering menjadi kunci keberhasilan pemasaran jangka panjang, Kotler dan Keller (2008). Perusahaan yang ingin membentuk ikatan pelanggan yang kuat harus memperhatikan sejumlah pertimbangan yang beragam. Sekelompok peneliti melihat kegiatan membangun retensi dengan menambah manfaat keuangan, manfaat sosial, atau ikatan struktural. Berikut menjelaskan empat jenis kegiatan pemasaran (marketing) penting yang digunakan perusahaan untuk meningkatkan loyalitas (loyalty):

1) Berinteraksi dengan pelanggan, mendengarkan pelanggan merupakan hal penting dalam manajemen hubungan pelanggan. Beberapa perusahaan menciptakan mekanisme berkelanjutan yang membuat manajer dapat terus terhubung dengan umpan balik pelanggan dari lini depan. Tetapi mendengarkan hanyalah sebagian dari cerita. Penting pula untuk menjadi advokat pelanggan dan sebisa mungkin memandang masalah dari sisi pelanggan, memahami sudut pandang mereka.

2) Mengembangkan program loyalitas (loyalty), dua program loyalitas pelanggan (customer loyalty) yang dapat ditawarkan perusahaan adalah program frekuensi dan program pemasaran klub. Program frekuensi dirancang untuk memberikan penghargaan kepada pelanggan yang sering membeli dan dalam jumlah besar. Program ini dapat membantu membangun loyalitas (loyalty) jangka panjang dengan pelanggan, menciptakan peluang lintas penjualan dalam proses. Dipelopori oleh maskapai penerbangan, hotel dan perusahaan kartu kredit, kini program frekuensi (Frequency Program / FP) dipakai oleh berbagai jenis bisnis, contoh sekarang sebagian besar supermarket menawarkan kartu klub yang memberikan diskon atas barangbarang tertentu kepada pelanggan. Umumnya, perusahaan yang memperkenalkan (Frequency Program / FP) dalam industri mendapatkan banyak manfaat, terutama jika pesaing lambat merespons. Setelah pesaing merespons,(Frequency Program / FP) bisa menjadi beban keuangan bagi semua perusahaan yang menawarkannya, tetapi beberapa perusahaan lebih efisien dan kreatif dalam mengelola (Frequency Program / FP) ini. Banyak perusahaan menciptakan program keanggotaan klub (club membership program) bisa terbuka bagi semua orang yang membeli produk dan jasa atau hanya terbatas bagi kelompok yang berminat atau mereka yang bersedia membayar sejumlah kecil iuran. Meskipun klub terbuka untuk membangun database atau menangkap pelanggan dari pesaing, klub keanggotaan yang terbatas merupakan pembangun loyalitas (loyalty) jangka panjang yang lebih kuat. Iuran dan syarat keanggotaan menutup pintu bagi orang-orang yang hanya mempunyai minat singkat terhadap produk perusahaan agar tidak bergabung, klub menarik dan mempertahankan pelanggan yang menghasilkan sebagian besar bisnis bagi perusahaan.

3) Mempersonalisasikan pemasaran (marketing), personel perusahaan dapat menciptakan ikatan yang kuat dengan pelanggan melalui setiap individu dan personalisasi hubungan. Intinya, perusahaan yang cerdas mengubah pelanggan mereka menjadi klien. Satu perbedaan yang berhasil disimpulkan adalah Institusi mungkin tidak mengenal nama pelanggan, tetapi perusahaan 
harus mengenal nama kliennya. Pelanggan dilayani sebagai bagian dari masa atau bagian dari segmen yang lebih besar, klien dilayani berdasarkan basis perorangan. Pelanggan dilayani oleh semua orang yang kebetulan bertugas, klien dilayani oleh profesional yang ditugaskan khusus untuk mereka.

4) Menciptakan ikatan institusional, perusahaan dapat memasok pelanggan dengan peralatan khusus atau hubungan komputer yang membantu pelanggan mengelola pesanan, penggajian dan persediaan. Pelanggan tidak teralu terbujuk untuk beralih ke pemasok lain jika peralihan itu melibatkan biaya modal tinggi, biaya riset tinggi atau hilangnya diskon pelanggan setia. Salah satu contoh yang bagus adalah McKesson Corporation, grosir farmasi terkemuka yang menginvestasikan jutaan dolar dalam kemampuan EDI untuk membantu apotek independen mengelola persediaan, proses input-pesanan dan ruang rak. Contoh lainnya adalah Milliken \& Company yang menyediakan program pranti lunak khusus riset pemasaran, pelatihan penjualan dan arahan penjualan kepada pelanggan setianya.

Menurut Gunawan Adisaputro (2010) terdapat 5 tingkat biaya investasi di dalam menjaga loyalitas pelanggan (customer loyalty):

1. Melakukan "basic marketing”: perusahaan hanya berupaya menjual produknya.

2. Melakukan "reactive marketing": pemasar mendorong keberanian pelanggan untuk bersediia menghubungi perusahaan bilamana menghadapi kesulitan. Perusahaan menyediakan akses yang cukup untuk dapat dihubungi.

3. Melakukan "accountable marketing": perusahaan melakukan checking dengan menanyakan kepada pelanggan apakah merasa terpenuhi harapannya.

4. Melakukan "proactive marketing": pemasar menghubungi pelanggan secara regular dari waktu ke waktu.

5. Melakukan "partnership marketing": Bekerja sama secara teratur dan berlanjut dengan pelanggan-pelanggan yang besar dengan tujuan membantu mereka memperbaiki kinerja perusahaan mereka.

Loyalitas pelanggan (customer loyalty) memberi perusahaan keunggulan kompetitif yang berkelanjutan seiring berjalannya waktu dan karena itu merupakan kunci kesuksesan, Seto-Pamies (2012). Tujuan suatu perusahaan sangat menginginkan terciptanya loyalitas pelanggan (customer loyalty).

\section{METODE PENELITIAN}

Adil dan Jujur (Justice) merupakan suatu kondisi dimana pelanggan merasa mendapatkan perlakuan yang adil dan jujur ketika melakukan transaksi dengan perusahaan, Edwards (2002) menyatakan bahwa perlakuan adil berpotensi menimbulkan delight. Pelayanan terbaik (esteem) adalah suatu kondisi dimana pelanggan merasa mendapatkan pelayanan yang sangat baik dari perusahaan, 
sehingga menimbulkan perasaan diistimewakan. Edwards (2002) menyatakan bahwa pelanggan yang merasa diperlakukan secara personal, diperhatikan self esteem mereka dan merasa nyaman, maka akan berpotensi menimbulkan delight. Surprised / Finishing Touch merupakan kondisi dimana pelanggan merasa mendapatkan pelayanan atau fasilitas yang tidak pernah diduga sebelumnya, teori ini dirujuk dari penelitian Oliver, et.al. (1997) dimana surprised merupakan salah satu fakta penting dalam delight. Edwards (2002) menyatakan bahwa pelanggan perlu untuk mendapatkan rasa percaya dan merasa aman.

Berdasarkan karakteristik permasalahan yang membahas pengaruh adil dan jujur (justice), pelayanan terbaik (esteem) dan surprised / finishing touch sebagai variabel-variabel customer delight terhadap loyalitas pelanggan (customer loyalty) Es Teler 77 di Jakarta Pusat Tahun 2019, maka penelitian ini menggunakan metode kuantitatif (quantitative research). Muri Yusuf (2014), dijelaskan bahwa dalam kerangka penelitian terutama penelitian kuantitatif (quantitative research), populasi merupakan salah satu hal yang esensial dan perlu mendapat perhatian dengan seksama apabila peneliti ingin menyimpulkan suatu hasil yang dapat dipercaya dan tepat guna obyek penelitiannya.

Penelitian ini menggunakan teknik pengumpulan data dalam bentuk data primer melalui penyebaran kuesioner yaitu teknik pengumpulan data yang dilakukan dengan cara memberi seperangkat pertanyaan atau pernyataan tertulis kepada responden untuk dijawab (Sugiyono, 2005). Data primer adalah data yang diperoleh langsung dari sumber data yang dikumpulkan secara khusus dan berhubungan langsung dengan permasalahan yang diteliti.

Penelitian ini menggunakan metode kuantitatif (quantitative research) dan jenis data yang digunakan adalah data cross section. Dimana sumber data diperoleh dengan proses penyebaran kuesioner yang dibagikan kepada pelanggan yang datang dan makan di Es Teler 77 yang berada di Jakarta Pusat, selama kurun waktu 3 (tiga) bulan dari periode bulan Januari sampai dengan bulan Maret 2019. Hasil kuesioner akan menjadi sumber perolehan data mengenai topik yang akan dibahas.

Data primer diperoleh dengan menggunakan daftar pertanyaan yang telah terstruktur dengan tujuan untuk mengumpulkan informasi dari responden. Skor masing-masing indikator variabel yang diperoleh dari pengisian kuesioner yang telah dibagikan kepada responden merupakan sumber data primer dalam penelitian ini. Untuk mencari jawaban atas permasalahan yang peneliti cari, peneliti lebih tertuju pada kuesioner tertutup dimana kuesioner tersebut terdapat lima alternatif jawaban yang harus dipilih oleh responden tanpa kemungkinan memberikan jawaban lain yaitu dengan menggunakan Skala Likert. Skala ini dimaksudkan untuk mengukur sikap individu dalam dimensi yang sama dan individu menempatkan dirinya ke arah satu kontinuitas dari butir soal (Muri Yusuf, 2014). Data sekunder dalam penelitian ini adalah berupa data pelanggan Es Teler 77 di Jakarta Pusat. Data tersebut diolah lebih lanjut untuk memperoleh jumlah sampel yang akan digunakan dalam penelitian ini. Metode pengambilan data yang digunakan dalam penelitian ini menggunakan metode purposive sampling yaitu merupakan tipe pemilihan sampel secara tidak acak yang informasinya diperoleh 
dengan menggunakan pertimbangan atau kriteria tertentu. Kriteria sampel yang digunakan adalah sebagai berikut:

1) Pelanggan yang datang dan makan di Es Teler 77 Jakarta Pusat

2) Pelanggan yang datang dan makan di Es Teler 77 Jakarta Pusat, minimal 5 (lima) kali dalam sebulan

3) Pelanggan yang datang dan makan di Es Teler 77 Jakarta Pusat yang telah menikmati minimal 3 (tiga) jenis makanan

Sampel yang digunakan dalam penelitian ini menggunakan metode perhitungan sampel dengan rumus yang dikemukakan oleh Slovin yang dikutip dalam bukunya Muri Yusuf (2014), dengan menggunakan nilai tingkat kepercayaan $90 \%$ dan $\bar{\alpha}$ sebesar $10 \%$. Instrumen yang digunakan dalam penelitian ini adalah data-data yang diperoleh dari penyebaran kuesioner kepada responden, selanjutnya data hasil kuesioner tersebut akan diolah dengan skala likert untuk mendapatkan nilai dari variabel-variabel yang diterdiri dari: adil dan jujur (justice), pelayanan terbaik(esteem), surprised /finishing touch dan loyalitas pelanggan (customer loyalty). Data-data yang diperoleh dari responden terlebih dahulu diolah dalam bentuk tabel data statistik dengan menggunakan program microsoft office excel 2010 dan kemudian tabel data statistik tersebut diolah dengan menggunakan program software Eviews 7.0 untuk menganalisa pengaruh antar variabel independen terhadap variabel dependen melalui pendekatan metode analisis regresi linier berganda.Kegiatan pengolahan data dengan Microsoft Office Excel 2010 meliputi pembuatan tabel data. Pengujian signifikansi analisis regresi linier berganda dengan data cross section menggunakan Eviews 7.0 sebagai program pengolahan datanya. Eviews merupakan program yang banyak digunakan dalam pendidikan, pemerintah dan industri. Meskipun sebagian besar Eview dirumuskan oleh ekonom, program ini sendiri juga dapat digunakan dalam bidang studi, seperti sosiologi, statistik, keuangan, dll (Basuki, Prawoto, 2016). Analisis regresi linier berganda ini dapat digunakan untuk memperoleh gambaran yang menyeluruh mengenai hubungan antara variabel dependen dan independen secara menyeluruh baik simultan maupun parsial. Alat analisis dalam penelitian ini diterjemahkan dalam variabel-variabel yang digunakan untuk analisa regresi berganda adalah sebagai berikut:

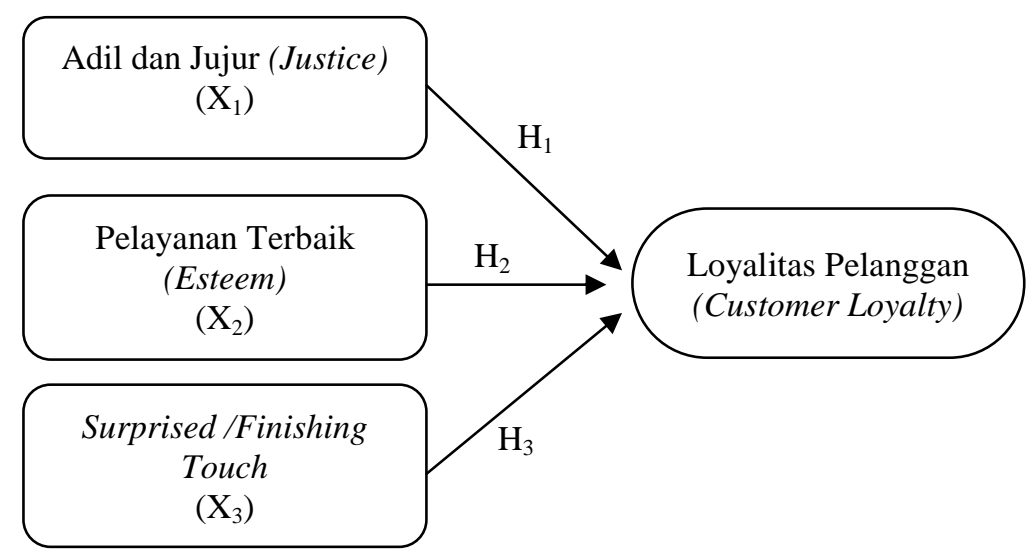




\section{Diagram 1. \\ Variabel Y Loyalitas Pelanggan (Customer Loyalty), Variabel $\mathrm{X}_{1}$ Adil dan Jujur (Justice), Variabel $\mathbf{X}_{2}$ Pelayanan Terbaik (Esteem) dan Variabel $\mathbf{X}_{3}$ Surprised /Finishing Touch.}

\section{HASIL DAN PEMBAHASAN}

\section{Gambaran Umum dan Objek Penelitian}

Es teler adalah jenis minuman dingin berupa buah-buahan segar, nangka, alpukat dan kelapa, dengan racikan sirup istimewa yang membuat minuman ini asyik untuk dinikmati. Pada tahun 1981, seorang Ibu bernama Murniati Widjaja memenangkan lomba membuat Es Teler di Jakarta. Bermula dari lomba inilah, timbul sebuah gagasan untuk membuka warung tenda sederhana di plataran teras sebuah pertokoan duta merlin di kawasan Jakarta Pusat. Warung sederhana dengan nama Es Teler 77 ini merupakan usaha keluarga yang ditangani langsung oleh Ibu Murniati sendiri bersama suaminya Trisno Budijanto, anak dan mantunya, Yenny Setia Widjaja dan Sukyatno Nugroho. Pada tahun 1987, Sukyatno Nugroho mewaralabakan Es Teler 77 yang dengan ini merupakan usaha makanan cepat saji asli Indonesia pertama yang menerapkan sistem waralaba, mengikuti perkembangan tren gaya hidup. Pada tahun 1994, seluruh gerai Es Teler 77 dipindahkan dari kios ke mal dan plaza. Kehadiran Es Teler 77 di arena pusat perbelanjaan modern ini memperluas wawasan kuliner Indonesia, dimana Es Teler 77 memperkenalkan konsep makanan cepat saji (fastfood) yang menyajikan makanan dan minuman jajanan populer Indonesia. Setelah lebih dari tiga dasawarsa, Es Teler 77 terus berkembang dengan menyajikan produk makanan dan minuman dengan resep orisinil yang bermutu dan berkualitas kepada pelanggan di pelosok Indonesia dan juga mancanegara. Dengan 180 gerai lebih yang tersebar di berbagai daerah di Indonesia, Es Teler 77 bukan hanya meningkatkan citra makanan Indonesia di negeri sendiri tetapi juga memperkenalkan makanan Indonesia ke mancanegara, hingga saat ini Es Teler 77 dapat dikunjungi di Singapura, Malaysia dan Melbourne, Australia.

Dalam penelitian ini bertujuan untuk melihat bagaimanakah pengaruh dari variabel-variabel adil dan jujur (justice), pelayanan terbaik (esteem), surprised / finishing touch terhadap loyalitas pelanggan (customer loyalty)Es Teler $77 \mathrm{di}$ Jakarta Pusat tahun 2019. Data yang digunakan adalah data cross section dengan jumlah responden sebesar 100 pelanggan Es Teler 77 sebagai responden.

\section{Profil Responden Penelitian}

Profil diperoleh dari penyebaran kuesionersebesar 100 (seratus)responden yang dilakukan selama bulan Januari sampai dengan bulan Maret tahun 2019. Sampel yang digunakan dalam penelitian ini menggunakan metode perhitungan sampel dengan rumus yang dikemukakan oleh Slovin (Muri Yusuf, 2014) dengan menggunakan nilai tingkat kepercayaan $90 \%$ dan $\bar{\alpha}$ sebesar $10 \%$. Pada penelitian 
ini, jumlah pelanggan yang datang dan makan di Es Teler 77 yaitu 869,152 pelanggan.

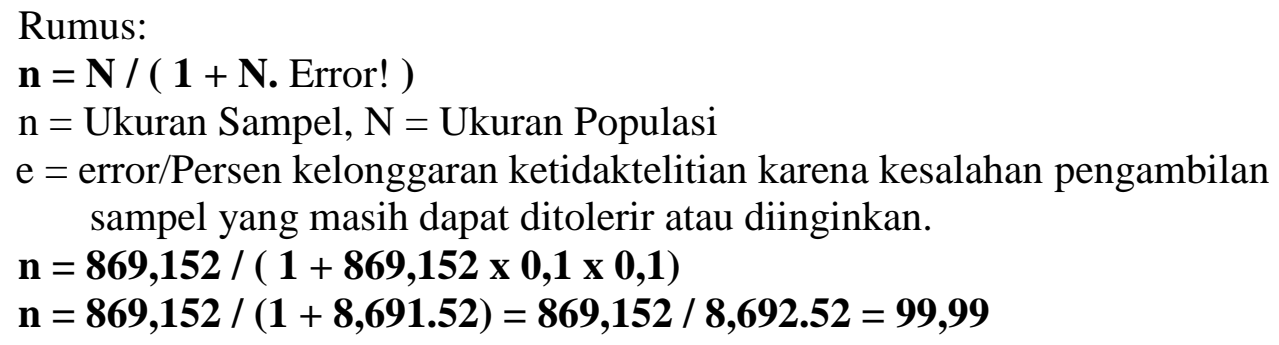

Berdasarkan perhitungan di atas maka jumlah sampel dalam penelitian ini sebanyak 99,99 yang dibulatkan menjadi 100 responden. Dengan demikian jumlah sampel penelitian minimal sebanyak 100 orang.

\section{a. Jenis Kelamin}

Data Jenis Kelamin diperoleh dari penyebaran kuesioner sebesar 100 (seratus) responden bulan Januari sampai dengan bulan Maret tahun 2019. Berikut data Jenis Kelamin ditampilkan pada Diagram 1. Pada penelitian ini terlihat banyak responden wanita banyak yang datang dan makan di Es Teler 77 karena jenis makanan dan minumannya memang banyak disukai wanita.

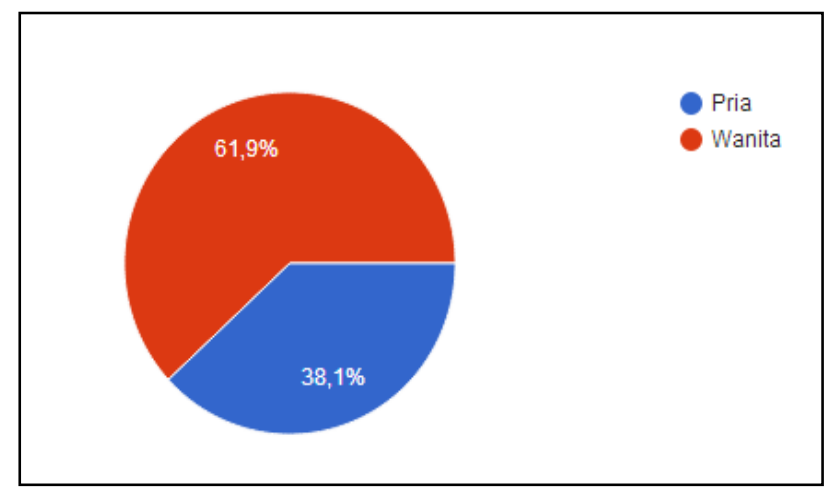

Diagram 1. Jenis Kelamin

Sumber : Data diolah, 2019

\section{b. Usia}

Data Usia diperoleh dari penyebaran kuesioner sebesar 100 (seratus) responden yang dilakukan selama bulan Januari sampai dengan bulan Maret tahun 2019. Berikut data tentang Usia ditampilkan pada Diagram 2. Pada penelitian ini terlihat banyak responden berusia 21 sampai 30 tahun yang datang dan makan di Es Teler 77 karena jenis makanan dan minumannya memang banyak disukai pada usia tersebut. 


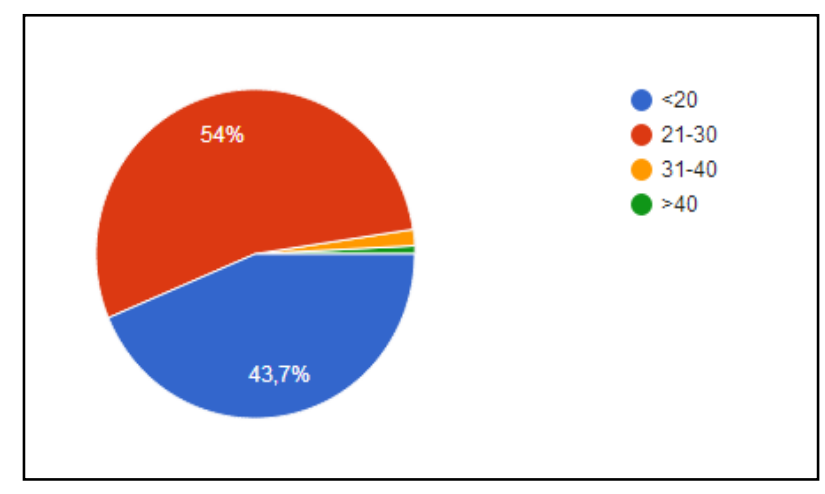

\section{Diagram 2.Usia Responden}

\section{c. Jenis Pekerjaan}

Sumber : Data diolah, 2019

Data Jenis Pekerjaan diperoleh dari penyebaran kuesionersebesar 100 (seratus) responden yang dilakukan selama bulan Januari sampai dengan bulan Maret tahun 2019. Berikut data tentang Jenis Pekerjaan ditampilkan pada Diagram 3. Pada penelitian ini terlihat banyak responden sebagai mahasiswa/pelajar yang datang dan makan di Es Teler 77 karena jenis makanan dan minumannya memang disukai serta harga yang terjangkau.

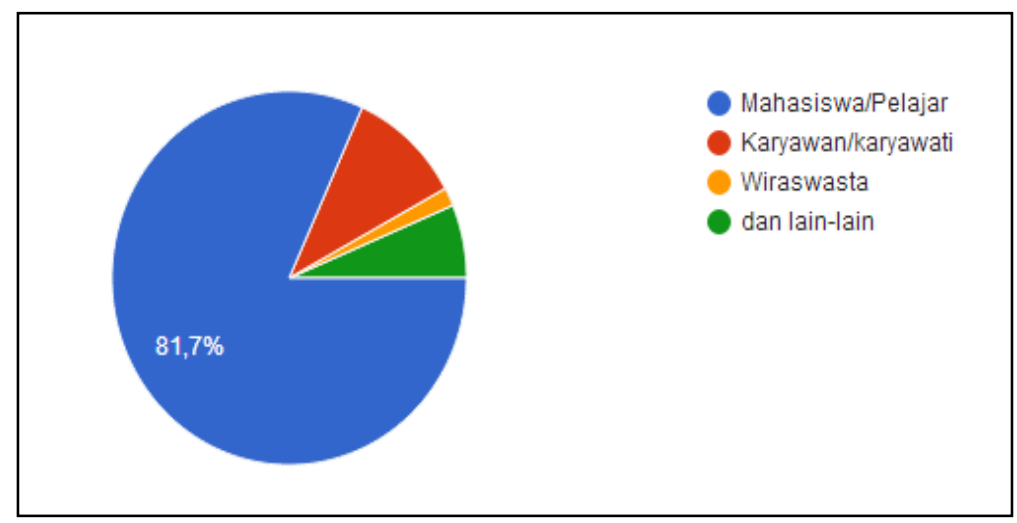

Diagram 3. Jenis Pekerjaan

Sumber : Data diolah, 2019

\section{Hasil Analisa Data}

\section{a. Uji Validitas (Validity)}

Validitas (validity) adalah tingkat keandalan dan kesahihan alat ukur yang digunakan. Instrumen dikatakan valid berarti menunjukkan alat ukur yang dipergunakan untuk mendapatkan data itu valid atau dapat digunakan untuk mengukur apa yang seharusnya diukur uji validitas bertujuan untuk mengetahui apakah ada pernyataan-pernyataan pada kuesioner yang harus diganti karena dianggap tidak valid. Berikut adalah uji validitas dari pernyataan-pernyataan yang termuat dari variabel-variabel: adil dan jujur (justice), pelayanan terbaik (esteem), surprised /finishing touch dan loyalitas pelanggan (customer loyalty) Es Teler 77 di Jakarta Pusat tahun 2019. 
Tabel 1. Uji Validitas Loyalitas Pelanggan (Customer Loyalty)

\begin{tabular}{cccccc}
\hline & $\mathbf{Q}_{\mathbf{1}}$ & $\mathbf{Q}_{\mathbf{2}}$ & $\mathbf{Q}_{\mathbf{3}}$ & $\mathbf{Q}_{\mathbf{4}}$ & $\mathbf{Q}_{\mathbf{5}}$ \\
\hline \hline $\mathrm{r}_{\text {hitung }}$ & 0.8366 & 0.8470 & 0.8752 & 0.8813 & 0.6876 \\
$\mathrm{r}_{\text {tabel }}$ & 0.1966 & 0.1966 & 0.1966 & 0.1966 & 0.1966 \\
$\mathrm{r}_{\text {hitung }}>\mathrm{r}_{\text {tabel }}$ & Valid & Valid & Valid & Valid & Valid \\
\hline \multicolumn{5}{c}{ Sumber : Data diolah, 2019 }
\end{tabular}

Dari Tabel 1 diatas tampak seluruh pernyataan kuesioner diajukan kepada 100 (seratus) responden. Nilai $r_{\text {tabel }}$ diperoleh melalui df (degree of freedom) $=\mathrm{n}$ 2 , yakni $\mathrm{df}=100-2=98$ dengan $\alpha=0.05$ atau $5 \%$ maka nilai $\mathrm{r}_{\text {tabel }}=0.1966$. Hasil perhitungan validitas dari 5 (lima) pernyataan untuk variabel loyalitas pelanggan (customer loyalty) tampak memiliki nilai $r_{\text {hitung }}$ lebih besar $r_{\text {tabel }}$, sehingga kelima pernyataan dari variabel loyalitas pelanggan (customer loyalty) Es Teler 77 dinyatakan valid.

Tabel 2. Uji Validitas Adil dan Jujur (Justice)

\begin{tabular}{|c|c|c|c|c|}
\hline & $\mathbf{Q}_{1}$ & $\mathbf{Q}_{2}$ & $\mathbf{Q}_{3}$ & $\mathbf{Q}_{4}$ \\
\hline $\mathbf{r}_{\text {hitung }}$ & 0.7092 & 0.6831 & 0.7468 & 0.7552 \\
\hline $\mathrm{r}_{\text {tabel }}$ & 0.1966 & 0.1966 & 0.1966 & 0.1966 \\
\hline $\mathrm{r}_{\text {hitung }}>\mathrm{r}_{\text {tabel }}$ & Valid & Valid & Valid & Valid \\
\hline
\end{tabular}

Dari Tabel 2 diatas tampak seluruh pernyataan kuesioner diajukan kepada 100 (seratus) responden. Nilai $r$ tabel diperoleh melalui df (degree of freedom) $=$ $\mathrm{n}-2$, yakni $\mathrm{df}=100-2=98$ dengan $\alpha=0.05$ atau 5\% maka nilai $\mathrm{r}$ tabel $=0.1966$. Hasil perhitungan validitas dari 4 (empat) pernyataan untuk variabel adil dan jujur (justice) tampak memiliki nilai $r_{\text {hitung }}$ lebih besar $r_{\text {tabel }}$, sehingga keempat pernyataan dari variabel adil dan jujur (justice) dinyatakan Valid.

Tabel 3. Uji Validitas Pelayanan Terbaik (Esteem)

\begin{tabular}{ccccc}
\hline & $\mathbf{Q}_{\mathbf{1}}$ & $\mathbf{Q}_{\mathbf{2}}$ & $\mathbf{Q}_{\mathbf{3}}$ & $\mathbf{Q}_{\mathbf{4}}$ \\
\hline \hline $\mathrm{r}_{\text {hitung }}$ & 0.7957 & 0.8838 & 0.8309 & 0.8298 \\
$\mathrm{r}_{\text {tabel }}$ & 0.1966 & 0.1966 & 0.1966 & 0.1966 \\
$\mathrm{r}_{\text {hitung }}>\mathrm{r}_{\text {tabel }}$ & Valid & Valid & Valid & Valid \\
\hline \hline \multicolumn{4}{c}{ Sumber : Data diolah, 2019 }
\end{tabular}

Dari Tabel 3 diatas tampak seluruh pernyataan kuesioner diajukan kepada 100 (seratus) responden. Nilai $\mathbf{r}_{\text {tabel }}$ diperoleh melalui df (degree of freedom) $=\mathrm{n}$ 2 , yakni df $=100-2=98$ dengan $\alpha=0.05$ atau 5\% maka nilai $\mathrm{r}_{\text {tabel }}=0.1966$. Hasil perhitungan validitas dari 4 (empat) pernyataan untuk variabel pelayanan terbaik (esteem) tampak memiliki nilai $\mathrm{r}_{\text {hitung }}$ lebih besar $\mathrm{r}_{\text {tabel }}$ sehingga keempat pernyataan dari variabel pelayanan terbaik (esteem) dinyatakan valid. 


\section{Tabel 4. Uji Validitas Surprised /Finishing Touch}

\begin{tabular}{ccccc}
\hline & $\mathbf{Q}_{\mathbf{1}}$ & $\mathbf{Q}_{\mathbf{2}}$ & $\mathbf{Q}_{\mathbf{3}}$ & $\mathbf{Q}_{\mathbf{4}}$ \\
\hline \hline $\mathrm{r}_{\text {hitung }}$ & 0.6569 & 0.7289 & 0.7746 & 0.7747 \\
$\mathrm{r}_{\text {tabel }}$ & 0.1966 & 0.1966 & 0.1966 & 0.1966 \\
$\mathrm{r}_{\text {hitung }}>\mathrm{r}_{\text {tabel }}$ & Valid & Valid & Valid & Valid \\
\hline \hline \multicolumn{4}{c}{ Sumber : Data diolah, 2019 }
\end{tabular}

Dari tabel 4diatas tampak seluruh pernyataan kuesioner yang diajukan kepada 100 (seratus) responden. Nilai $\mathrm{r}_{\text {tabel }}$ diperoleh melalui df (degree of freedom $)=\mathrm{n}-2$, yakni $\mathrm{df}=100-2=98$ dengan $\alpha=0.05$ atau $5 \%$ maka nilai $\mathrm{r}_{\text {tabel }}=$ 0.1966. Hasil perhitungan validitas dari 4 (empat) pernyataan untuk variabel Surprised / Finishing Touch tampak memiliki nilai $\mathbf{r}_{\text {hitung }}$ lebih besar $\mathbf{r}_{\text {tabel }}$ sehingga ke-4 butir pernyataan dari variabel Surprised / Finishing Touch dinyatakan valid.

\section{b. Uji Reliabilitas (Realibility)}

Uji reliabilitas (reliability) dilakukan untuk mengetahui sejauh mana suatu instrumen dapat memberikan hasil yang relatif sama bila dilakukan pengukuran kembali pada subyek yang sama. Berikut ini adalah perhitungan uji reliabilitas (reliability) dari instrumen-instrumen yang termuat dari variabel-variabel : adil dan jujur (justice), pelayanan terbaik(esteem), surprised finishing touch dan loyalitas pelanggan (customer loyalty) Es Teler 77 di Jakarta Pusat.

Tabel 5. Uji Reliabilitas (Reliabitility)

\begin{tabular}{lccc}
\hline & $\boldsymbol{r}_{\text {hitung }}$ & Alpha Cronbach & \\
\hline \hline Loyalitas Pelanggan & 0.8497 & $>0,8-1,00$ & Sangat Reliabel \\
Justice & 0.8497 & $>0,8-1,00$ & Sangat Reliabel \\
Esteem & 0.8497 & $>0,8-1,00$ & Sangat Reliabel \\
Finishing Touch & 0.8497 & $>0,8-1,00$ & Sangat Reliabel \\
\hline \multicolumn{4}{c}{ Sumber : Data diolah, 2019 }
\end{tabular}

Dari Tabel 5 diatas tampak seluruh pernyataan dari instrumen-instrumen yang termuat pada variabel-variabel: adil dan jujur (justice), pelayanan terbaik(esteem), surprised/finishing touchdan loyalitas pelanggan (customer loyalty) Es Teler 77 dalam kuesioner yang diajukan kepada 113 (seratus tiga belas) responden. Hasil perhitungan reliabilitas dari 4 (empat) instrumeninstrumen yang termuat pada variabel-variabel: adil dan jujur (justice), pelayanan terbaik (esteem), surprised / finishing touch dan loyalitas pelanggan (customer loyalty) Es Teler 77, tampak memiliki nilai $\mathrm{r}$ hitung berada diantara Alpha Cronbach (>0.8-1.00) sehingga keempat instrumen-instrumen yang termuat pada variabel-variabel : adil dan jujur (justice), pelayanan terbaik (esteem), surprised / finishing touch dan loyalitas pelanggan (customer loyalty) Es Teler 77 dalam kuesioner yang diajukan, dinyatakan sangat reliabel. 


\section{c. Uji Stabilitas Model}

Uji ini menggunakan Recursive Least Squares dilakukan untuk mengetahui apakah parameter model regresi bersifat stabil dalam periode penelitian.

Gambar 1. Recursive Least Squares Test

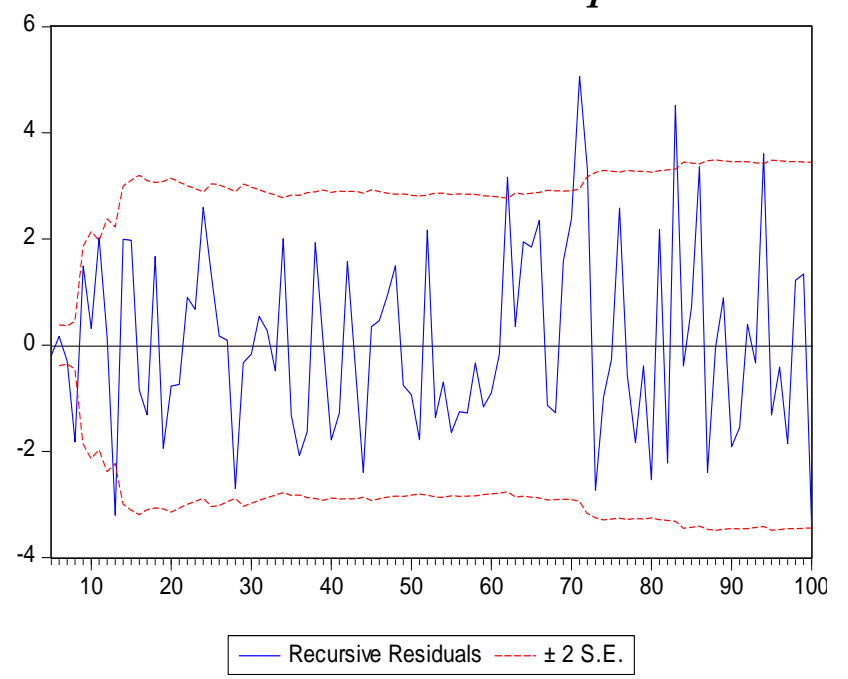

Sumber: Data diolah, 2019

Berdasarkan Uji Stabilitas Model dengan menggunakan Recursive Least Squares Test pada Gambar 1 diatas tampak recursive residual berada di dalam band sehingga menunjukkan kestabilan parameter estimasi di dalam periode penelitian.

\section{d. Uji Linieritas}

Linieritas merupakan asumsi awal yang seharusnya ada dalam model regresi linier. Uji linieritas dapat dengan mudah dilakukan pada regresi linier sederhana bertujuan untuk mengetahui apakah pemilihan model regresi linier sudah tepat atau tidak. Uji linieritas ini menggunakan Uji Ramsey RESET (Regression Specification Error Test). Untuk menguji tepat atau tidaknya model regresi linier dalam penelitian ini maka hipotesis yang digunakan adalah sebagai berikut :

$\mathrm{H}_{0}$ : Model Regresi bersifat stabil (linier)

$\mathrm{H}_{1}$ : Model Regresi bersifat tidak stabil (non linier)

dengan ketentuan :

Nilai Probabilitas $\mathrm{F}_{\text {hitung }}>\alpha 0.05$ : Gagal menolak $\mathrm{H}_{0}$

Nilai Probabilitas $\mathrm{F}_{\text {hitung }}<\alpha 0.05$ : Menolak $\mathrm{H}_{0}$, Menerima $\mathrm{H}_{1}$ 
Tabel 6. Ramsey Reset Test

\begin{tabular}{|c|c|c|c|}
\hline \multicolumn{4}{|c|}{$\begin{array}{l}\text { Ramsey RESET Test } \\
\text { Equation: EQ01 } \\
\text { Specification: LOYALITAS C JUSTICE ESTEEM } \\
\text { FINISHING_TOUCH } \\
\text { Omitted Variables: Squares of fitted values }\end{array}$} \\
\hline & Value & $\mathrm{df}$ & Probability \\
\hline t-statistic & 0.914687 & 95 & 0.3627 \\
\hline F-statistic & 0.836653 & $(1,95)$ & 0.3627 \\
\hline Likelihood ratio & 0.876832 & 1 & 0.3491 \\
\hline
\end{tabular}

Sumber : Hasil olah data Eviews 7, 2019

Berdasarkan Uji Ramsey Reset pada Tabel 6 diatas tampak nilai probabilitas dari $\mathrm{F}_{\text {hitung }}$ sebesar 0.3627 . Sedangkan tingkat kesalahan dalam penelitian ini menggunakan $\alpha 0.05(5 \%)$, maka dapat disimpulkan nilai probabilitas $\mathrm{F}_{\text {hitung }}$ sebesar $0.3627>\alpha_{0.05}(5 \%)$. Artinya gagal menolak $\mathrm{H}_{0}$ sehingga parameter model regresi dalam penelitian ini bersifat stabil atau linier.

\section{e. Uji Normalitas}

Uji ini dilakukan untuk mengetahui apakah model regresi yang digunakan dalam penelitian memiliki variabel residual yang berdistribusi normal, dengan hipotesis sebagai berikut:

$\mathrm{H}_{0}$ : Variabel Residual pada Model Regresi yang digunakan berdistribusi normal

$\mathrm{H}_{1}$ : Variabel Residual pada Model Regresi yang digunakan tidak berdistribusi normal

dengan ketentuan:

Nilai $\mathrm{JB}_{\text {hitung }}<$ Chi Squares : Gagal menolak $\mathrm{H}_{0}$

Nilai $\mathrm{JB}_{\text {hitung }}>$ Chi Squares : Menolak $\mathrm{H}_{0}$, Menerima $\mathrm{H}_{1}$

\section{Tabel 7. Uji Normalitas}

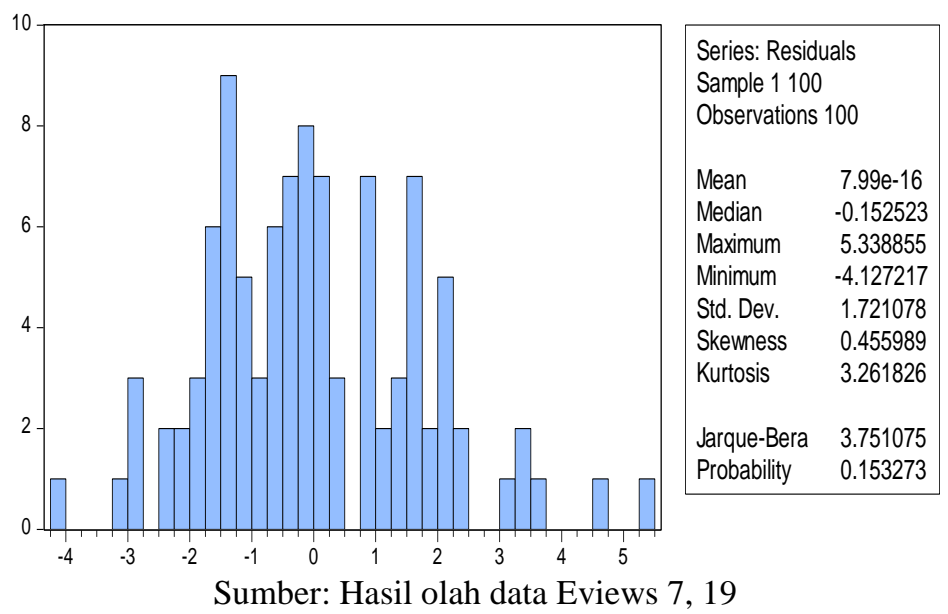


Hasil pengujian histogram tampak terlihat simetris dan bila dibentuk garis di tiap titiknya maka akan membentuk pola lonceng yang menandakan pola distribusi normal, selain itu Jarque-Bera yang dilakukan menggunakan program Eviews 7 pada penelitian ini menghasilkan hitungan sebesar 3.751075 dengan probability 0.153273 . Jika dilihat berdasarkan nilai chi-squares dengan menggunakan $\alpha=5 \%$ dan df $=4$, maka nilai chi-squares adalah sebesar 9.49. Dengan dasar pengambilan keputusan sebagai berikut:

$\mathrm{H}_{0}$ : Variabel Residual pada Model Regresi yang digunakan berdistribusi normal

$\mathrm{H}_{1}$ : Variabel Residual pada Model Regresi yang digunakan tidak berdistribusi normal

Berdasarkan hasil tersebut tampak bahwa nilai statistik uji Jarque - Bera adalah JB $(3.751075)<X^{2}(9.49)$ atau p-value $(0.153273)>\alpha_{(0.05)}$, maka hipotesis nol gagal ditolak yang artinya residual dari model penelitian terdistribusi normal sehingga uji $\mathrm{t}$ dan uji $\mathrm{F}$ bisa dilakukan untuk melihat signifikansi model dan berdasarkan hasil uji normalitas yang telah dilakukan diatas maka diperoleh hasil perhitungan regresi berganda Tabel 8 berikut :

\section{Tabel 8. Hasil Pengujian Regresi}

\begin{tabular}{|c|c|c|c|c|}
\hline \multicolumn{5}{|c|}{$\begin{array}{l}\text { Dependent Variable: Loyalitas } \\
\text { Method: Least Squares } \\
\text { Date: 04/15/17 Time: } 23: 11 \\
\text { Sample: } 1100 \\
\text { Included observations: } 100\end{array}$} \\
\hline Variable & Coefficient & Std. Error & t-Statistic & Prob. \\
\hline C & -1.557014 & 0.980711 & -1.587638 & 0.1157 \\
\hline Justice & 0.573347 & 0.116931 & 4.903294 & 0.0000 \\
\hline Esteem & 0.363247 & 0.091068 & 3.988758 & 0.0001 \\
\hline Finishing Touch & 0.503199 & 0.081157 & 6.200331 & 0.0000 \\
\hline R-squared & 0.726447 & \multirow{7}{*}{\multicolumn{2}{|c|}{$\begin{array}{l}\text { Mean dependent var } \\
\text { S.D. dependent var } \\
\text { Akaike info criterion } \\
\text { Schwarz criterion } \\
\text { Hannan-Quinn criter. } \\
\text { Durbin-Watson stat }\end{array}$}} & 13.00000 \\
\hline Adjusted R-squared & 0.717899 & & & 3.290636 \\
\hline S.E. of regression & 1.747763 & & & 3.993728 \\
\hline Sum squared resid & 293.2487 & & & 4.097935 \\
\hline Log likelihood & -195.6864 & & & 4.035902 \\
\hline F-statistic & 84.97920 & & & 1.986906 \\
\hline Prob(F-statistic) & 0.000000 & & & \\
\hline
\end{tabular}

Sumber: Hasil olah data Eviews 7, 2019

Hasil pengujian regresi dilakukan dengan menggunakan analisis regresi berganda dengan data time series sebagaimana terlihat pada tabel diatas. Selanjutnya dari tabel regresi tersebut akan dilakukan pengujian asumsi klasik yang terdiri dari: Uji Multikolinearitas dan Uji Heteroskedastisitas.

\section{f. Uji Asumsi Klasik}

Sebelum dilakukan pengujian regresi linier berganda terhadap hipotesis penelitian, maka terlebih dahulu perlu dilakukan suatu pengujian untuk mengetahui ada tidaknya pelanggaran terhadap asumsi-asumsi klasik. Hasil pengujian hipotesis yang baik adalah pengujian yang tidak melanggar asumsi- 
asumsi klasik yang mendasari model regresi linier berganda. Asumsi-asumsi klasik dalam penelitian ini meliputi uji multikolinearitas dan uji heteroskedastisitas.

\section{Uji Multikolinearitas}

Uji Multikolinieritas digunakan untuk menguji apakah model regresi ditemukan adanya korelasi antar variabel bebas atau dengan kata lain untuk melihat ada atau tidaknya hubungan yang linier antara variabel bebas didalam regresi berganda didalam persamaan Y (LOYALITAS $)=\beta_{0}+\beta_{1}($ JUSTICE $)+$ $\beta_{2}($ ESTEEM $)+\beta_{3}($ FINISHING TOUCH $)+e$

Pengujian terhadap ada tidaknya multikolinearitas dilakukan dengan menggunakan metode koefisien korelasi antara variabel independen. Jika koefisien korelasi antar variabel independen diatas 0.85 maka diduga ada multikolinieritas dalam model. Sebalik bila koefisien korelasi antar variabel independen dibawah 0,85 maka tidak terdapat gejala multikolinieritas dalam model.

Tabel 9. Uji Multikolinearitas

\begin{tabular}{|c|c|c|c|}
\hline & Justice & Esteem & Finishing Touch \\
\hline Justice & 1.000000 & 0.686051 & 0.457829 \\
\hline Esteem & 0.686051 & 1.000000 & 0.334996 \\
\hline Finishing Touch & 0.457829 & 0.334996 & 1.000000 \\
\hline
\end{tabular}

Sumber: Hasil olah data Eviews 7, 2019

Dari hasil uji koefisien korelasi antar variabel independen, tidak terdapat multikolinieritas antara varibel-variabel independen Justice, Esteem dan Finishing Touch. Dimana nilai korelasi antar variabel independen Justice, Esteem dan Finishing Touch tersebut bernilai dibawah 0.85 .

\section{Uji Heteroskedastisitas}

Untuk menentukan heteroskedastisitas dalam penelitian menggunakan glejser. Heteroscedasticity merupakan salah satu tes untuk residual dari hasil regresi dengan OLS. Dengan adanya heteroscedasticity, estimasi dengan OLS masih konsisten, tapi standar erornya menjadi tidak valid.Dalam hal ini berarti varians yang didapat tidak efisien. Dasar pengambilan keputusan dalam uji heteroskedastisitas ini adalah sebagai berikut:

$\mathrm{H}_{0}$ : Tidak ada heterokedastisitas

$\mathrm{H}_{1}$ : Ada heterekodastisitas 


\section{Tabel 10. Uji Heteroskedastisitas}

\section{Heteroskedasticity Test: Glejser}

\begin{tabular}{llll}
\hline \hline F-statistic & 1.272477 & Prob. F(3,96) & 0.2882 \\
Obs*R-squared & 3.824412 & Prob. Chi-Square(3) & 0.2811 \\
Scaled explained SS & 3.797146 & Prob. Chi-Square(3) & 0.2842 \\
\hline \hline
\end{tabular}

Sumber : Hasil olah data Eviews 7, 2019

Dari hasil Uji Glejser dapat diketahui bahwa tidak terdapat masalah heterokedastisitas pada observasi dalam penelitian ini. Hal ini tampak pada nilai probabilitas Chi Square $(0.2811)>\alpha=5 \%(0.05)$. Dengan tidak adanya masalah Heteroskedastisitas maka estimator OLS tidak menghasilkan estimator yang BLUE karena estimator tidak memiliki varian yang minimum, artinya: 1) Perhitungan standard error metode OLS bisa dipercaya kebenarannya. 2) Interval estimasi dan uji hipotesis $\mathrm{t}$ dan $\mathrm{f}$ tetap bisa digunakan untuk evaluasi hasil regresi.

\section{g. Uji Hipotesis}

\section{Uji T}

Uji hipotesis ini dilakukan untuk mengetahui ada/atau tidaknya pengaruh variabel bebas dengan variabel terikatnya secara parsial. Hasil analisis antara variabel independen yaitu Justice, Esteem dan Finishing Touch terhadap variabel dependen yaitu Loyalitas Pelanggan Es Teler 77. Dengan menggunakan program Eviews 7 diperoleh hasil perhitungan pada Tabel 11.

\section{Tabel 11 Uji Hipotesis (Parsial t)}

Dependent Variable: Loyalitas Pelanggan

\begin{tabular}{lllll}
\hline Variable & Coefficient & Std. Error & $\mathbf{t}_{\text {Statistic }}$ & Prob. \\
\hline \hline C & -1.557014 & 0.980711 & -1.587638 & 0.1157 \\
Justice & 0.573347 & 0.116931 & 4.903294 & 0.0000 \\
Esteem & 0.363247 & 0.091068 & 3.988758 & 0.0001 \\
Finishing Touch & 0.503199 & 0.081157 & 6.200331 & 0.0000 \\
\hline \hline
\end{tabular}

Sumber: Hasil olah data Eviews 7, 2019

Dari hasil perhitungan untuk Uji t dari variabel adil dan jujur (justice) diperoleh $t_{\text {hitung }}$ sebesar 4.903294 dengan probabilitas sebesar 0.0000. Dasar pengambilan keputusan untuk variabel adil dan jujur (justice) sebagai berikut:

$\mathrm{H}_{0}$ : Tidak terdapat pengaruh adil dan jujur(justice)terhadap loyalitas pelanggan (customer loyalty)Es Teler 77 di Jakarta Pusat Tahun 2019

$\mathrm{H}_{1}$ : Terdapat pengaruh adil dan jujur(justice)terhadap loyalitas pelanggan (customer loyalty)Es Teler 77 di Jakarta Pusat Tahun 2019 
Dengan menggunakan dasar keputusan seperti diatas, diketahui berdasarkan tabel distribusi $\mathrm{t}$ dua sisi pada $\mathrm{df}=(\mathrm{N}-\mathrm{K})$ atau 100-4 $=96$ dengan $\alpha=5 \%$ diperoleh nilai $t_{\text {tabel }}$ sebesar 1.98498. Maka dapat disimpulkan $t_{\text {hitung }}$ (4.903294) > $\mathrm{t}_{\text {tabel }}$ (1.98498), yang artinya menolak $\mathrm{H}_{0}$ dan menerima $\mathrm{H}_{1}$. Sehingga hipotesis pertama yang diajukan menyatakan bahwa terdapat pengaruh adil dan jujur(justice)terhadap loyalitas pelanggan (customer loyalty) Es Teler 77 di Jakarta Pusat Tahun 2019, dapat diterima.

Berikutnya hasil perhitungan untuk Uji t dari variabel pelayanan terbaik (esteem)diperoleh $t_{\text {hitung }}$ sebesar 3.98876 dengan probabilitas sebesar 0.0001 . Dasar pengambilan keputusan untuk variabel pelayanan terbaik (esteem) sebagai berikut:

$\mathrm{H}_{0}$ : Tidak terdapat pengaruh pelayanan terbaik (esteem) terhadap loyalitas pelanggan (customer loyalty) Es Teler 77 di Jakarta Pusat Tahun 2019

$\mathrm{H}_{1}$ : Terdapat pengaruh pelayanan terbaik (esteem) terhadap loyalitas pelanggan (customer loyalty) Es Teler 77 di Jakarta Pusat Tahun 2019

Dengan menggunakan dasar keputusan seperti diatas, diketahui berdasarkan tabel distribusi $\mathrm{t}$ dua sisi pada $\mathrm{df}=(\mathrm{N}-\mathrm{K})$ atau 100-4 $=96$ dengan $\alpha=5 \%$ diperoleh nilai $t_{\text {tabel }}$ sebesar 1.98498. Maka dapat disimpulkan $t_{\text {hitung }}(3.98876)>$ $\mathrm{t}_{\text {tabel }}(1.98498)$, yang artinya menolak $\mathrm{H}_{0}$ dan menerima $\mathrm{H}_{1}$. Sehingga hipotesis kedua yang diajukan menyatakan bahwa terdapat pengaruh pelayanan terbaik (esteem) terhadap terhadap loyalitas pelanggan (customer loyalty) Es Teler $77 \mathrm{di}$ Jakarta Pusat Tahun 2019, dapat diterima.

Selanjutnya hasil perhitungan untuk Uji t dari variabel surprised/ finishing touch diperoleh $\mathrm{t}_{\text {hitung }}$ sebesar 6.200331 dengan probabilitas sebesar 0.0000. Dasar pengambilan keputusan untuk variabel surprised/finishing touch sebagai berikut:

$\mathrm{H}_{0}$ : Tidak terdapat pengaruh surprised/ finishing touch terhadap loyalitas pelanggan (customer loyalty)Es Teler 77 di Jakarta Pusat Tahun 2019

$\mathrm{H}_{1}$ : Terdapat pengaruhsurprised/finishing touch terhadap loyalitas pelanggan (customer loyalty)Es Teler 77 di Jakarta Pusat Tahun 2019

Dengan menggunakan dasar keputusan seperti diatas, diketahui berdasarkan tabel distribusi $\mathrm{t}$ dua sisi pada $\mathrm{df}=(\mathrm{N}-\mathrm{K})$ atau 100-4 $=96$ dengan $\alpha=5 \%$ diperoleh nilai $t_{\text {tabel }}$ sebesar 1.98498. Maka dapat disimpulkan $t_{\text {hitung }}(6.200331)>$ $\mathrm{t}_{\text {tabel }}$ (1.98498), yang artinya menolak $\mathrm{H}_{0}$ dan menerima $\mathrm{H}_{1}$. Sehingga hipotesis ketiga yang diajukan menyatakan bahwa terdapat pengaruh surprised/finishing touch terhadap loyalitas pelanggan (customer loyalty) Es Teler 77 di Jakarta Pusat tahun 2019, dapat diterima.

\section{Uji F}

Uji $\mathrm{F}$ digunakan untuk mengetahui pengaruh variabel independen yaitu Justice, Esteem dan Finishing Touch secara bersama-sama terhadap variabel dependen yaitu Loyalitas Pelanggan Es Teler 77. Dengan menggunakan program Eviews 7 diperoleh hasil perhitungan pada Tabel 12. 


\section{Tabel 12.Uji Hipotesis (Simultan f)}

\begin{tabular}{|l|l|}
\hline F-statistic & 84.97920 \\
\hline Prob(F-statistic) & 0.000000 \\
\hline \multicolumn{2}{|c|}{ Sumber : Hasil olah data Eviews 7, 2019} \\
\hline
\end{tabular}

Dari hasil perhitungan tersebut, dapat diketahui bahwa hasil uji $\mathrm{F}_{\text {hitung }}$ sebesar 84.97920 dengan probabilitas sebesar 0.000000. Dasar pengambilan keputusan untuk uji $\mathrm{F}_{\text {test }}$ ini adalah sebagai berikut:

$\mathrm{H}_{0}$ : Tidak terdapat pengaruh adil dan jujur(justice), pelayanan terbaik (esteem)dan surprised/finishing touch secara bersama-sama terhadap loyalitas pelanggan (customer loyalty) Es Teler 77 di Jakarta Pusat tahun 2019

$\mathrm{H}_{1}$ : Terdapat pengaruh adil dan jujur(justice), pelayanan terbaik (esteem)dan surprised/finishing touch secara bersama-sama terhadap loyalitas pelanggan (customer loyalty)Es Teler 77 di Jakarta Pusat tahun 2019

Dengan menggunakan dasar keputusan seperti diatas, diketahui berdasarkan $\mathrm{F}_{\text {tabel }}$ dengan $\mathrm{df}=3,96$ dengan $\alpha=5 \%$ diperoleh nilai $\mathrm{F}_{\text {tabel }}$ sebesar 2.70. Maka dapat disimpulkan $\mathrm{F}_{\text {hitung }}(84.97920)>\mathrm{F}_{\text {tabel }}(2.70)$, yang artinya menolak $\mathrm{H}_{0}$ dan menerima $\mathrm{H}_{1}$. Sehingga hipotesis keempat yang diajukan bahwa terdapat pengaruh adil dan jujur (justice), pelayanan terbaik (esteem) dan surprisedfinishing touch secara bersama-sama terhadap loyalitas pelanggan (customer loyalty) Es Teler 77 di Jakarta Pusat tahun 2019, dapat diterima.

\section{h. Koefisien Determinasi}

Koefisien Determinasi $\left(\mathrm{R}^{2}\right)$ untuk melihat seberapa baik garis regresi menjelaskan datanya (goodness of fit), artinya bagaimana garis regresi yang dibentuk sesuai dengan data. Jika semua data terletak pada regresi atau dengan kata lain semua nilai residual adalah nol maka kita mempunyai garis regresi yang sempurna (Widarjono, 2013). Koefisien Determinasi $\left(\mathrm{R}^{2}\right)$ pada intinya adalah untuk mengukur seberapa jauh kemampuan model dalam menerangkan variabel dependennya (Nathaniel, 2008). Hasil perhitungan Koefisien Determinasi $\left(\mathrm{R}^{2}\right)$ dari penelitian ini dapat dilihat pada Tabel 13 dengan menggunakan program Eviews 7.

\section{Tabel 13. Koefisien Determinasi $\left(\mathbf{R}^{2}\right)$}

\begin{tabular}{|l|l|}
\hline R-squared & 0.726447 \\
\hline Adjusted R-squared & 0.717899 \\
\hline \multicolumn{2}{|c|}{ Sumber : Hasil olah data Eviews 7, 2019}
\end{tabular}

Dari hasil perhitungan tersebut diperoleh besarnya pengaruh variabel independen terhadap variabel dependen yang dapat diterangkan oleh model dalam persamaan ini adalah sebesar 0.726447 atau sebesar $72.64 \%$. Hal ini menunjukan bahwa variasi dari variabel-variabel adil dan jujur (justice), pelayanan terbaik (esteem) dan surprised/finishing touch mampu menjelaskan variasi naikturunnya loyalitas pelanggan (customer loyalty) Es Teler 77 sebesar $72.64 \%$ sedangkan sisanya sebesar $27.36 \%$ dijelaskan oleh variabel-variabel selain adil dan 
jujur(justice), pelayanan terbaik (esteem) dan surprised/finishing touch yang tidak dimasukan dalam model regresi ini.

\section{E. SIMPULAN}

Berdasarkan hasil penelitian dan pembahasan yang telah dikemukakan, maka kesimpulan yang dapat diambil dari hasil penelitian mengenai Analisis Pengaruh Customer Delight (Adil dan Jujur (Justice), Pelayanan Terbaik (Esteem) dan Surprised/Finishing Touch) Terhadap Loyalitas Pelanggan Es Teler 77 di Jakarta Pusat Tahun 2019 adalah sebagai berikut:

1. Variabel adil dan jujur(justice) secara parsial memiliki nilai koefisien korelasi yang positif dan signifikan terhadap loyalitas pelanggan (customer loyalty )Es Teler 77 di Jakarta Pusat tahun 2019 sebesar 0.573347. Sedangkan hasil perhitungan uji t untuk adil dan jujur (justice), dimana $t_{\text {hitung }}$ $>t_{\text {tabel }}$. Hasil penelitian ini mengindikasikan bahwa dari 100 responden Es Teler 77 menyatakan bahwa adil dan jujur (justice) mempengaruhi loyalitas pelanggan (customer loyalty) Es Teler 77 di Jakarta Pusat tahun 2019. Hal ini dikarenakan Es Teler 77 menyajikan menu yang sesuai pada daftar gambar menu, pelayanan yang diberikan sesuai dengan waktu dan order, sehingga pelanggan merasa diperlakukan secara adil dan jujur dalam pelayanan yang diberikan.

2. Variabel pelayanan terbaik (esteem)secara parsial memiliki nilai koefisien korelasi yang positif dan signifikan terhadap loyalitas pelanggan (customer loyalty)Es Teler 77 di Jakarta Pusat tahun 2019 sebesar 0.363247. Sedangkan hasil perhitungan uji t untuk variabel pelayanan terbaik (esteem), dimana $t_{\text {hitung }}>t_{\text {tabel }}$. Hasil penelitian ini mengindikasikan bahwa dari 100 responden pelanggan es teler menyatakan bahwa pelayanan terbaik (esteem)mempengaruhi loyalitas pelanggan (customer loyalty) Es Teler 77 di Jakarta Pusat tahun 2019. Hal ini dikarenakan adanya sikap dari pelayan Es Teler 77 yang memberikan senyum, sapa, salam kepada pelanggan ketika pelanggan datang maupun meninggalkan restoran dan juga cepat tanggap dalam menerima pesanan pelanggan, sehingga pelanggan mendapatkan pelayanan terbaik.

3. Variabel surprised/finishing touchsecara parsial memiliki nilai koefisien korelasi yang positif dan signifikan terhadap loyalitas pelanggan (customer loyalty)Es Teler 77 di Jakarta Pusat tahun 2019 sebesar 0.503199. Sedangkan hasil perhitungan uji $\mathrm{t}$ untuk variabel Finishing Touch (Surprised), dimana $t_{\text {hitung }}>t_{\text {tabel }}$. Hasil penelitian ini mengindikasikan bahwa dari 100 responden pelangganes telermenyatakan bahwa surprised/ finishing touch) mempengaruhi loyalitas pelanggan (customer loyalty) Es Teler 77 di Jakarta Pusat tahun 2019. Hal ini dikarenakan Es Teler 77 memberikan promo di event tertentu sehingga pelanggan merasakan kepuasan tersendiri ketika mengunjungi Es Teler 77 dan setiap pelayan berusaha membuat para pelanggan merasa diprioritaskan.

4. Variabel adil dan jujur(justice), pelayanan terbaik (esteem)dan surprised/ finishing touchsecara bersama-sama berpengaruh terhadaployalitas 
pelanggan (customer loyalty)Es Teler 77 di Jakarta Pusat tahun 2019. Hal ini ditunjukan dengan nilai F-test, dimana $\mathrm{F}_{\text {hitung }}>\mathrm{F}_{\text {tabel }}$.

5. Dari Uji Koefisien Determinasi tampak bahwa variabel adil dan jujur (justice), pelayanan terbaik (esteem) dan surprised/finishing touch mampu menjelaskan variasi naik turunnya loyalitas pelanggan (customer loyalty) Es Teler 77 di Jakarta Pusat tahun 2019 sebesar 72.64\%, sedangkan sisanya sebesar $27.36 \%$ dijelaskan oleh variabel-variabel selain adil dan jujur (justice), pelayanan terbaik (esteem) dan surprised/finishing touch yang tidak dimasukan dalam model regresi ini.

Berdasarkan penelitian ini memberikan gambaran bahwa adil dan Jujur (justice), pelayanan terbaik (esteem)dansurprised/ finishing touch sangat berpengaruh terhadap loyalitas pelanggan (customer loyalty) Es Teler 77 di Jakarta Pusat tahun 2019, sehingga Es Teler 77 harus tetap menjaga kualitas pelayanannya, sehingga pelanggan merasa puas dan setiap perusahaan juga ingin pelanggannya agar tetap loyal terhadap perusahaan. Untuk kedepannya agar lebih dapat meningkatkan kepuasan pelanggan dari sisi lain, maka dapat diteliti analisis faktor-faktor diluar customer delight (adil dan jujur (justice), pelayanan terbaik (esteem) dan surprised/ finishing touch) seperti lamanya durasi hubungan pelanggan dengan perusahaan, biaya peralihan, ketidakpastian informasi, dan lainlain yang diharapkan dapat menghasilkan penjelasan yang lebih akurat tentang hubungan antara kesenangan pelanggan (customer delight) dan loyalitas pelanggan (customer loyalty).

\section{DAFTAR PUSTAKA}

Adisaputro, Gunawan. 2010. Manajemen Pemasaran Analisi Untuk Perancangan Strategi Pemasaran. UPP Sekolah Tinggi llmu Manajemen YKPNYogyakarta.

Ariefianto, Moch. Doddy. 2012. Ekonometrika: Esensi dan Aplikasi dengan menggunakan Eviews. Penerbit Erlangga. Jakarta.

Arikunto, S. 2002. Prosedur Penelitian : Suatu Pendekatan Praktek. Rineka Cipta. Jakarta.

Aryani, Dwi. Febrina Rosinta. 2010. Pengaruh Kualitas Layanan Terhadap Kepuasan Pelanggan Dalam Membentuk Loyalitas Konsumen. Bisnis dan Birokrasi, Jurnal Ilmu Administrasi dan Organisasi, Mei-Agustus 2010; 114-126.

Basuki, AT. Prawoto, N. 2016. Analisis Regresi Dalam Penelitian ekonomi dan Bisnis (Dilengkapi Aplikasi SPSS dan Eviews). PT Raja Grafindo Persada. Jakarta.

Edwards, D. 2002. Delight: Introduction to a New Metric and New Way of Thinking, (online), www.strategicvision.com. 
Finn, A. 2005. Reassessing The Foundation of Customer Delight. Journal of Service Research, 8 (2); 104-116.

Griffin, Jill. 2005. Customer Loyalty (Menumbuhkan dan Mempertahankan Kesetiaan Pelanggan). Penerbit Erlangga. Jakarta.

Hanselman, A. 2005. Seven Steps to Creating Customer Experience That Delight, (online), www.spookyaction.com.

Keiningham, L. Et al. 2004. The Role of Customer Delight in Achieving Loyalty, (online), www.Ipsosloyalty.com.

Kotler, Philip. Kevin Lane Keller. 2008. Manajemen Pemasaran. Penerbit Erlangga, Jakarta.

Kotler, Philip. 2010. Marketing 3.0. Penerbit Erlangga, Jakarta.

L. Daft, Richard. 2014. Era Baru Manajemen. Penerbit : Salemba Empat-Jakarta.

Lovelock, Christopher. H. Lauren K Right. 2007. Manajemen Pemasaran Jasa. Indeks. Jakarta.

Mascarenhas, A. et al. 2004. Customer Value Chain Involvement for Co-creating Customer Delight. Journal of Consumer Marketing, 21 (7); 486-496.

Nordman, C. 2004. Understanding Customer Loyalty and Disloyalty - The Effect of Loyalty - Supporting Factors and Repressing Factors, (online), www.hanken.fi.

Oliver, L. et al. 1997. Customer Delight: Foundations, Findings, and Managerial Insight. Journal of Retailing, 73 (3); 311-336.

Poster, R. 2001. Customer Delight, (Online). www.thebussinesscenter.com

Raharso, S. 2005. Pengaruh Customer Delight terhadap Behavior Intention Battery. Jurnal Wirausaha, 34 (5); 45-53.

Seto-Pamies, D. 2012. Customer Loyalty to Service Providers: Examining The Role of Service Quality, Customer Satisfaction, and Trust", Total Quality Management, 23 (11); 1257-1271.

Sugiono. 2005 Metode Penelitian Bisnis. Pusat Bahasa Depdiknas. Bandung.

Terry, R. George. 2014. Prinsip-Prinsip Dasar Manajmen. Bumi Aksara. Jakarta.

Tjiptono, F. 2002. Manajemen Jasa. Andi Off-set. Yogyakarta.

Widarjono, Agus. 2013. Ekonometrika Pengantar dan Aplikasinya. UPP STIM YKPN. Yogyakarka.

Yusuf, A. Muri. 2014. Metode Penelitian: Kuantitatif, Kualitatif dan Penelitian Gabungan. Prenadamedia Group. Jakarta. Edisi Pertama. 